\title{
WASTE MANAGEMENT IN UIN SUMATERA UTARA (A TRANSDICIPLINER APPROACH)
}

\author{
SUKIATI \\ UIN Sumatera Utara \\ Email: sukiatisugiono@uinsu.ac.id \\ DOI: $h t t p: / / d x$. doi.org/10.24952/fitrah.v5i2.1951
}

\begin{abstract}
This study aims to describe the waste management at UIN North Sumatra Campus. This research is a qualitative research. Data collected by observation and interview. Several strategies were carried out in this research, namely the sensitization of awareness through campaigns, training and action by forming forums and movements. The results of this study were analyzed with approach 3 (three approaches); Islamic Theology of Waste Management; Moral and Character Education Approach in Waste Management and Social Approach to Waste Management. By a theological approach, waste management should be approached with the belief that paying attention to waste must be based on the belief that it is all at the command of God and His apostles. The character approach implies that caring for this, is a good character and integral to his theological beliefs. The social approach gives awareness to the attitude that waste is not something that is simply ignored but must be a concern and be carried out with integrated cooperation.
\end{abstract}

Keywords: Waste Management, Trash and Campus, Transdisciplinary Approach

\begin{abstract}
Abstrak
Penelitian ini bertujuan untuk mendeskripsikan pengelolaan sampah di Kampus UIN Sumatera Utara. Penelitian ini adalah penelitian kualitatif, data dikumpulkan dengan cara observasi dan wawancara. Beberapa strategi dilakukan dalam penelitian ini, yaitu sensitisasi akan kesadarana melalui kampanye, pelatihan dan aksi dengan oembentukan forum dan gerakan. Hasil penelitian ini dianalisis dengan pendekatan 3 (tiga pendekatan); Teologi Islam tentang Pengelolaan Sampah; Pendekatan Pendidikan Akhlak dan Karakter dalam hal Pengelolaan Sampah dan Pendekatan Sosial terhadap Pengelolaan Sampah. Dengan pendekatan teologi, pengelolaan sampah sebaiknya didekati dengan keyakinan bahwa memperhatikan sampah harus didasari keyakinan bahwa itu semua atas perintah Allah dan rasulNya. Pendekatan karakter menanamkan bahwa kepedulian terhadap sampah adalah suatu karakter yang baik dan integral dengan keyakinan teologinya. Pendekatan sosial memunculkan sikap bahwa sampah bukan sesuatu yang diabaikan begitu saja tetapi harus kepedulian yang harus dilaksanakan dengan kerjasama yang Terintegrasi.
\end{abstract}

Kata Kunci: Pengelolaan Sampah, Sampah dan Kampus, Pendekatan Transdisipliner 
FITRAH Jurnal Kajian Ilmu-ilmu Keislaman

Vol. 05 No. 2Desember 2019

\section{INTRODUCTION}

A campus consisting of thousands of students consumes all kinds of needs every day. It can be estimated that the amount of which reaches thousands, the amount of waste produced every day must be so many ranging from plastic waste to paper waste. This is needed by a program or technology to overcome this.

But there are still many campuses that even the Islamic campus does not yet have a good awareness of waste management, even though the Islamic concept of cleanliness they teach is even attached to the name of their institution. This is also still a problem for Islamic Universities in North Sumatra State Islamic University (UIN).

UIN North Sumatra, a higher education institution labeled as Islam, is interesting to be used as a research area where UIN North Sumatra is a prestigious educational institution, which already has three strata; first degree, second degree for the master's program and third degree for the doctoral program. This shows that UIN North Sumatra should have awareness and action on good waste management.

It is undeniable that environmental issues such as waste, it really needs the involvement and role of all parties. Because environmental problems are problems that have a relationship between one another, including the participation of the community including campuses or universities that care about waste issues. The concern of the campus community in this matter must always be improved so that the problems faced can be solved together and done easily.

The assisted community of this research is the campus community, both academics and non-academics. Academics include educators, education staff and students. From non-academics, that is, every individual involved in campus activities ranging from janitors, park officials and canteen owners and servants.

UIN North Sumatra Medan has eight (8) Faculties and 63 Study Programs (Majors) or majors. 417 lecturers and educational staff are 151 civil servants and 136 non-civil servants are employees and around 17,000 students. Cleaning staff are assigned by outsourcing as many as 65 officers, who are tasked with handling office and classroom and outdoor room cleanliness.

The selection of this campus as research assistance has several reasons. First, this campus is a campus that has been classified for quite a long time since 
before becoming a state university, this campus has been aged 48 years. Like a human with such an age, this campus has a productive period in seeing the problems that are in its institution. Second, most of the campus community is an educated community who have good insight into the problems they face. Third, the Islamic Values adopted by the campus impress the campus community's religious understanding of cleanliness and waste management to be good. Fourth, community empowerment programs and Waste management is being discussed and promoted by various groups of people. This choice requires that the North Sumatra UIN campus also pay attention to good waste management, at least in line with community trends. Fifth, the leadership behavior tends to lead to good change by supporting planned programs that provide opportunities for UIN North Sumatra to advance.

Researchers coordinate with informants, educators and educators on campus to update data relating to waste management on campus. Informants and campus community resource people already know how waste management in their area can be a source of data for this assisted research.

Before outsourcing, the problem of trash on campus was managed by the Household College. Work of cleaning, gardening, garbage disposal, and others are carried out by the Household section consisting of Civil Servants (PNS), Permanent Daily Employees (PHT) and Freelance Daily Employees (PHL). After outsourcing, waste management and cleanliness are carried out by PT. Kesuma Jaya Selayang (KJS) which is also still under the supervision of the Higher Education Household section.

Trash is managed conventionally. Conventional trash management is intended that the trash is broomed, thrown into a garbage can and discharged into a larger landfill. This waste is then left or burned or transported by a garbage carrier to the final landfill ) in Tanjung Morawa. Waste production on campus originates from student and lecturer classes, employee office waste, canteen waste, garden waste, and other wastes. Various types of campus waste are produced, starting from paper, plant or organic waste, plastic waste and bottles from food and beverages.

Researchers with stakeholders who assisted UIN North Sumatra campus identified several hopes for this waste management problem. First, there was a change in attitude and behavior related to the improvement of the understanding of the campus community, especially those related to waste and maintaining 
cleanliness, disposing of trash, and trash management. In this case, it will be instilled to the public about the teachings of Islamic law relating to maintaining cleanliness and managing trash in the middle of the campus community. Secondly, the lack of ignorance, prevalence and severity of this trash problem so that it does not recur even even dealt with systematic handling of waste. Students, lecturers, employees, leaders and campus community are aware of the importance of properly disposing of trash. The sorting of trash according to its type. treated and used properly. There are several ways to sort waste according to the type of trash. Researchers can use and utilize the experience of other community trash management or other institutions as a benchmarking or measurement tool for waste management in UIN North Sumatra. Third, increasing awareness for the campus community including leaders so that policies can be expected to support cleanliness and trash management programs, maintain cleanliness and properly dispose of trash. Fourth, the realization of the provision of campus community with lifeskill, provision of skills that have economic value by utilizing trash, as a form of resolution of the problem of trash management on campus. Fifth, the formation of a trash management group among the campus community as a follow up of this waste management assistance activity.

\section{METHOD}

This research is a qualitative research. The strategy strategies undertaken are the first, by raising awareness. Sensitization is intended to arouse public awareness of the North Sumatra UIN campus about the importance of maintaining cleanliness, disposing of waste properly and managing waste that provides good benefits for beauty, campus cleanliness can also provide economic benefits.

Ignorance toward cleanliness is a number of conditions that could hinder the efforts of tertiary institutions to increase their bargaining power at national and international events. In the first stage, this awareness raising strategy is to provide guidance through interviews from students, lecturers, employees, janitors and managers canteen.This awareness can also be done by promoting environmental awareness, for example by moving the campus community to create a waste sorting movement. This creative initiative can provide great 
benefits for the environment, education and health. In this assistance the strategy will find or identify the problems they face but have not yet they realize.

In addition, the participation of assisted groups and stakeholders was also carried out. The involvement of assistants and stakeholders is one of the keys to the success and sustainability of the program's activities. Participation is not meant only at the level of information (information) and consultation. Assistance is also involved at a higher level of participation in decision making about the types of program activities carried out, as well as in the implementation of program activities (acting together) and in monitoring / evaluation.

Coordination with stakeholders aims to get information on what other people have done, experiences done by others, best practices or lesson learned from previous programs.

With the above strategy, researchers conducted several steps in program activities such as the following, re-mapping the problem with the Participatory Rural Appraisal (PRA) method. Brainstorming and FGD techniques are applied to collect data that confirms the next program steps. Furthermore, the inculcation of Islamic legal values regards cleanliness and waste management according to Islam. At the basic level, planting an understanding of cleanliness and waste management has a positive impact on correct waste management and prevent waste neglect that may continue to emerge. There are two kinds of reinforcement through this education. First, the counseling class for students and lecturers; provide reinforcement of Islamic legal values with hygiene education and waste management. Second, educate the campus community about the values of Islamic law regarding cleanliness of waste management. Training the importance of managing waste and determining which types of waste will be a priority in handling waste management together.

Empowerment of the campus community by utilizing waste that has been prioritized in determining identification. Empowerment is carried out with plastic diet training. This training has positive implications for the formation of plastic diet forums and making creative works of making plastic waste that has economic value for its members.

Empowerment of waste management through the plastic diet program has been carried out since 2015. Therefore, the assistance research related to waste management through the plastic diet is a follow-up or follow-up for the waste management program for the new assistance. 
The parties involved are campus residents consisting of students, educators and educational staff managing the canteen and others. As a target group and beneficiary. Leaders, Officers and Policy Makers will be involved in making decisions to be embraced to support the program. Researchers. As program proponents, researchers facilitate the mentoring process developed with leaders, campus residents and officials. Researchers together with stakeholders will make training that contains material about the concept of campus waste management. Campus cleanliness and waste management. Personnel at this institution are partners in working, collecting waste and processing waste. They can work voluntarily in this program. Expert staff in community assistance from aspects expected to equip the community with life skills (lifeskill). This is intended as an additional program so that victims and the community do not dwell on the problems they are experiencing.

\section{RESULT}

From interviews conducted an action plan to become a waste management solution on the North Sumatra UIN campus has priorities including:

1. Increase campus community awareness through awareness campaigns and rubbish care campaigns such as making stickers, posters and banners.

2. Conduct training on waste management. Considering that plastic waste often cannot be handled easily, in this case the Waste Compassion Movement training will be conducted.

3. The campus facilitates facilities and infrastructure for waste management such as the provision of trash bins according to the type of waste

4. The policy of the leadership regarding waste management and sanctions for those who do not obey the rules of disposing waste properly.

5. Discipline the cleaning staff because they are slow in coming and slow in cleaning.

6. Increase the number of janitors

7. Promote reduce and reuse activities before reaching the recycle.

8. Form a forum to care for waste and the forum for Merciful Waste in the campus.

The first solution plan is to increase the awareness of campus residents through awareness campaigns and waste care campaigns such as by making 
stickers, posters and banners. Stickers, posters and banners contain slogans related to waste, including: (1) Your trash is your responsibility! (2) Let's Care about Trash! (3) Partial Cleansing of Faith (4) Waste Can Be Money. Don't Throw Out Random Money! (5) Trash Can Bring Disasters (6) Trash Can Make You Rich! (7) Waste does not have to be thrown away, but recycled! (8) Trash! I was thrown away, now I'm loved! (9) Clean is Beautiful! (10) Clean the body, clean the clothes, clean the environment! Increased awareness is in line with an environmentally friendly program (green), zero waste.

Second is conducting training socialization on waste management. Considering that plastic waste can often not be easily overcome, this will be done in the case of Trash Compassion training. But before that, it is necessary to do training in the sorting of wastes and the usefulness of this sorting. This plan supports the next activity to continue the campaign of waste separation (Campaigning for waste segregation), namely by providing four garbage disposal bags for types of organic, glass or ceramic, paper and plastic waste, this will increase waste separation which automatically makes it easier for garbage collectors to transfer waste to the recycling site. This sorting of waste also means reducing waste to landfills. Some slogans were made to support this strategy such as: "Separate Trash by Type because They are not Muhrim! Apply fairly by placing trash according to its type! It's not only you who wants to be watched! The trash alsooo!!! "

Third, the next strategy is to involve the campus to participate in providing facilities and infrastructure for waste management such as the provision of trash bins according to the type of waste. Fourth, the policy of the leadership regarding waste management and sanctions for those who do not comply with the rules to dispose of waste properly. In this strategy the leadership is involved to issue a policy on waste management. With this policy, the North Sumatra UIN campus has regulations on waste management. very absolute, especially in giving birth to this regulation. Because of the lack of public awareness of the management of samaphs, it is necessary to get a little pressure that this is very important for campus residents in particular and the community in general. Without leadership participation, all planned waste management programs will be in vain. One approach to campus residents to be able to help the waste management program on the North Sumatra UIN campus in cleanliness is how to familiarize campus residents with behaviors that are 
consistent with the program's goals. This includes, among others, how to change the perception of campus residents regarding orderly and orderly waste management, social factors, structures, and local culture and habits in waste management so far.

Fifth, disciplining the waste management and cleaning staff because they are slow to come and slow to clean on one side and on the other hand there is a need for their direct commitment. Sixth, increasing the number of waste managers and cleaning workers. Cleaning staff in sufficient numbers to conduct waste management are very necessary, given the increasing number of students and residents of the North Sumatra UIN campus. Seventh, to promote reduce and reuse activities before reaching the recycle. Before the availability of recycle activities, at least the campus will promote reduce and reuse activities first.

Eighth, form a forum to care for rubbish and merciful forum for rubbish among the campus or even the Garbage bank. Garbage banks become a strategic step that can be used to overcome campus waste, so that rubbish becomes a profitable commodity. Making Garbage Banks facilitate campus residents in collecting waste which can then be exchanged for interesting goods or services. Reduce and reuse programs especially in plastic waste finally agreed upon as a priority. ${ }^{1}$

\section{Action}

From the priority of waste management there are several stages that will be carried out:

1. Increase campus residents' knowledge about waste and waste management.

At this stage an effort is made to increase knowledge about waste management, waste management regulations and the main concepts of waste management through brochures or handouts that are distributed free of charge to students, lecturers, staff and campus residents.

This section explains the main concepts of waste management which relies on reduction (minimization) since before the waste was formed. It is explained that $3 R$ (reduce, reuse and recycle) is the basis of waste

\footnotetext{
${ }^{1}$ Mohamad Rizal, "Analisis Pengelolaan Persampahan Perkotaan (Studi Kasus pada Kelurahan Boya Kecamatan Banawa Kabupaten Donggala)," Jurnal SMARTek, Vol. 9 No. 2. (Mei 2010), h. 6-7.
} 
management according to Law-18 / 2008. Waste management should be integrated in accordance with the characteristics of waste itself. But it all starts from the concept of waste minimization.

a. Trash Merciful Movement Training. After the socialization of knowledge about the concept of waste management simply. The next action taken was to conduct a Trash Merciful Movement training.

The training activities are based on the fact that there is a lot of plastic waste scattered on campus, on the road, in the trenches, in campus parks, and in almost every corner of the city and village. The danger posed by plastic waste is quite serious both for health and the threat of flooding during the rainy season.

On campus there is no one who cares about the threat of the dangers of this plastic waste. While as consumers, campus residents continue to spread trash wrapped / plastic bottles. They are free to use plastic bags for wrapping their merchandise. Likewise campus residents, arbitrarily throw bottles, plastic packaging and bags to any place. This phenomenon has been going on for decades since the campus was established.

Based on these realities, North Sumatra UIN needs to sponsor the Waste Compassion Movement, as a manifestation of the Islamic command to maintain cleanliness. This training activity is called the Pioneering Activity of the Trash Compassion Student Movement. campaigns for the dangers of plastic waste and is willing to invite traders and the public to carry out diets in the use of plastic.

In this activity as many as 40 students of North Sumatra UIN were involved as participants who at the same time will become organized volunteers who are ready to campaign for the urgency of cleanliness of plastic waste through the movement of compassionate rubbish in the community

Expected outcomes from this activity include (1) Small traders and campus residents, especially in the campus environment, increasingly understanding the dangers of plastic waste (2) Mothers who shop at the tavern or market always bring their own plastic baskets or bags. (3) The community does not carelessly dispose of plastic waste. 
This training program is carried out with three methods; a discussion of the dangers of plastics and their countermeasures; the formation of the Garbage Compassionate Student Movement Student Group; and Distribution of Brochures and Stickers for the Trash Compassion Student Movement.

The subject of discussion in the discussion is the Dangers of Plastic Waste to the Community The next material is the steps to Reduce the Use of Plastic Materials by Industry, Traders on Campus and Campus Residents.

Activities carried out in stages:

1) Discussion of the types of waste, patterns of managing waste and others

2) Formation of the Garbage Compassion Forum

3) Campaign and distribution of Environmental Awareness Brochures / Stickers through Waste Management Training

4) Training to process plastic bottles into flowers

The next step is to form the Garbage Compassion Forum and initiate the birth of a waste bank. In this section the effort to build a forum starts from the student group.

The Trash Compassion Forum that has been formed has produced several concrete works. Starting from utilizing used plastic from bottled beverage bottles, to be used as table decoration flowers, plastic bags. Then utilize wood waste as clothing material to be used as cigarette ashtrays and others. This activity has provided valuable experience to students, especially members of the forum on how to utilize plastic waste.

In addition to plastic diets, the Trash Compassion Forum has also begun to make a 'paper diet', which uses printed paper that has not been used to be used otherwise as a note paper or envelope.

b. Furthermore, assistance is provided at the leadership level to initiate serious and serious waste management at the North Sumatra UIN campus. This idea, of course, received a good response, it's just that its realization and implementation have not proceeded as expected. The good result is that efforts towards more serious waste management seem to have begun to be thought about by later providing more specific garbage bins. This new trash can consists of three colors. With the 
intention that there has been an initiation to organize waste segregation in three categories. These trash cans are red, green and yellow and have been placed in several places throughout the North Sumatra UIN campus.

\section{Evaluation and Reffection}

Evaluation of the residents of the North Sumatra UIN campus in waste management is one of the functions of management that aims to find out whether the implementation of waste management which includes waste collection, sorting and recycling is in accordance with a plan that is useful to increase community participation in controlling waste generation.

\section{Evaluation on Waste Management Traditions}

a. The tradition of waste management on the North Sumatra UIN campus is still far from what has been called environmentally friendly.

Environmentally friendly is meant to be environmentally friendly in the simplest sense. The campus members have not actively carried out, invited and provided facilitation to care for the environment starting from the place, class, office or environment in general. In environmentally friendly activities there are at least 3 things that are emphasized namely greening (green beahviors), waste management (waste management) with $3 R$ techniques and making biopori holes.

Green behaviorist such which is generally (or according to knowledge of environmental science) judged in the context of the considered society as a protective way of environmental behavior a attribute to the health environment. According to the above understanding, environmentally friendly behavior is understood as an activity that gives the smallest possible negative impact on the environment. This behavior is exemplified by a student who prefers to ride a bicycle when going to school. This student's motivation is motivated by the desire to reduce air pollution.

According to the Central Statistics Agency, environmentally friendly behavior can be demonstrated by the behavior, which includes housing facilities, energy utilization, water use, transportation use, waste management, environmental maintenance participation. 
Environmentally friendly indicators are not well met on the North Sumatra UIN campus. Where rubbish is still scattered, the tradition of throwing away friends by dumping them without trying to love them by storing them first and throwing them away until they find them with the trash. The use of water that is unplanned and maintained. The management of unsorted waste is part of the characteristics of waste management traditions that are not environmentally friendly.

b. Evaluation of Facilities and Infrastructure

In addition to the tradition of waste management that can be used to see whether the North Sumatra UIN campus is included in the category of environmentally friendly campus, facilities and infrastructure are one indicator that can be used as a benchmark for the success of waste management.

The environmentally friendly campus category follows 6 (six) main indicators, namely: (i) Layout and condition of campus facilities and infrastructure (ii) Energy utilization and anticipation of global warming (iii) Integrated waste management (iv) Utilization of water sparingly ( v) The use and creation of environmentally friendly transportation facilities and (vi) environmentally sound education.

UIN SU can pay attention to a number of things as input as follows. First, related to the arrangement of the campus, in the future should be increasingly enlarged the ratio of land not allotment of buildings that are used for green open space (for parks and campus forests). Second, the use of facilities and infrastructure that are able to save energy. Third, the utilization of recycling (recycling program for university waste). Fourth, related to the issue of water utilization, water conservation programs must continue to be carried out. Making infiltration wells and biopores must be done in the corner- corner of the building on campus. Fifth, if possible transportation in the future will prioritize the transportation of bicycles rather than machines. Consequently, the campus must provide a friendly environment for pedestrians and cyclists and bicycle parking lots. There is training, training and training related to environmental care and waste management on campus. In this context, the Vice Chancellor (WR) in Education (WR I) and WR Finance (WR II) has a big hand in solving this problem. On the other 
hand, student institutions that strive to improve the quality of the environment must be increasingly visible and increasingly visible

c. Evaluation on Leadership Policy

Indeed, garbage is identical to something that should be thrown away, burned, and destroyed. However, it should be in the hands of campus residents both lecturers and students, garbage is no longer something that should be thrown away, burned or destroyed. Those items turn out to be something beautiful, beautiful, and has more economic value, than before.

Especially in campus areas where the number of residents is not small, of course, it will have an impact on the amount of waste generated. Therefore, there needs to be innovation related to waste management on the North Sumatra UIN campus.

But before the innovation is carried out, it is necessary to have a policy on waste management seriously. The success of the management of this campus depends in part on the policies of the campus leadership.

1) Written commitment of campus leadership

2) Concern and awareness of campus residents

3) Behavior of campus residents

4) Facilities, facilities and infrastructure owned

Therefore, the leadership or officials of the North Sumatra UIN campus should give birth to policies or instructions that are intended to carry out serious waste management at least in the initial efforts to reduce waste to minimize the generation of ever-increasing waste.

\section{Reflections from a System Thinking Viewpoint: An Initial Effort of a Transdisciplinary Approach to Waste Management}

The System Thinking Framework can be used to look at waste issues and manage them as a transdisciplinary approach. The framework commonly used in Systems Thinking is the iceberg model. The model of an iceberg is a model that is described like an iceberg, where the thing that appears on the surface of the water from an iceberg is usually only the top, which looks smaller when the thing that is below the surface is actually bigger.

In systems thinking, what emerges is only a phenomenon or event. In the context of waste management in UIN North Sumatra, the phenomenon is that garbage is still scattered about, waste that is not managed properly 
except collected, collected and disposed of. The phenomenon or event of this garbage is something tangible that can be seen, felt and touched. Usually contains a lot of data. Below the surface, there are patterns of events or trends that affect phenomena or events that will form or occur. This section is actually historical patterns of events, across space and time. These patterns of events are hidden behind the phenomenon, where the patterns can be in the form of lack of awareness of campus residents or other things that affect the phenomenon the rubbish. So, this section gives us an understanding and makes us able to predict what will happen next.

By identifying the structure, we can make predictions better. Understanding the structure not only understands the pattern of events across space and time, but also understands what causes the pattern of events to occur. Deeper, the structure is formed due to mental models. Simply put, mental models are the way we see the world. Our perspective determines what we do. Understanding the mental model that works, makes us able to anticipate what new structures might be formed. This new structure does not necessarily solve the problem. It may be that it is a new form of the same problem.

When looked back up, our perspective on something will determine our action or response to something. Over time we will develop rules, facilities, and organizations to facilitate our actions or responses. We form structures. This structure then makes the results that appear always repeat the same all the time, and wherever we use the structure. Structure creates patterns. These patterns come to the surface in the form of events. Sometimes it becomes very phenomenal, sometimes only cursory events that are considered not too important.

In other words, the phenomenon of waste will probably appear repeatedly and even continuously if the structure and pattern behind it is still ongoing. In summary, for example, if we consider that the awareness of North Sumatra UIN residents about waste is still low as a structured pattern, then we will be able to predict the phenomenon of waste management in North Sumatra UIN will remain unchanged.

In terms of actions to make changes, the easiest level of work is to make changes to phenomena. At this level we can change the statistics, and events. Changing this phenomenon is by holding activities, which can give 
the impression that changes are happening and will occur. The next level that is more difficult is to make changes to the pattern. Changes to the pattern can be done with discipline and hard work. Through this we can do something, and give the impression of a change. The form is for example a semester or annual activity. So when discipline and hard work are stopped, activities not done then the changes are lost.

To make changes that are more strategic and longer term is to change the structure. Changing the structure, especially those that have been ripe for years, is not easy. We will face resistance or rejection from those in the structure for a long time. Therefore, changing the structure becomes very difficult and requires a long time. However, when the structure has changed, a new pattern of events will emerge which will ultimately affect the creation of new phenomena.

At the level of the subsurface icebergs is the most difficult level. Because it is usually the largest and broadest level and becomes the foundation of the formation of the iceberg to continue to the surface. This level is a change in mental model, or perspective. This part is difficult, because the mental position of the lowermost model of the foot of the iceberg is often invisible and unconscious, so the process of change requires patience and sufficient time to repeat the process continuously. However, when this basic level changes, the mental model becomes the foundation for new structures, new patterns, forming new phenomena or events. Changes in the ideal conditions desired change work itself.

System Thinking or System Thinking, or what is commonly referred to as holistic, or comprehensive thinking was later developed by Jay Forrester. The emphasis of systems thinking can be said to be on understanding the structure, what patterns of events arise from these structures and what causes these structures to occur.

This system of thinking is different from linear and reductionistic way of thinking. Reductionistic way of thinking, useful at the time of analysis, where we dissect parts of a phenomenon. However, this method cannot explain the new phenomena that arise as a result of the interaction of these various parts. The system is more than a collection or number of parts.

This system of thinking is basically a way of thinking that is shared by all humans, only because modern knowledge tends to be more reductionistic, 
eventually the way of thinking becomes a little different and difficult to accept. Especially in environmental studies including waste shows that nature is non-linear and complex.

Jay Forester developed a framework for the thought process known in the book Limits to Growth, which was launched in 1974. The message of this book: "that in a limited world, we cannot grow indefinitely." Johan Rochstrom also conveyed the results of his research that the boundaries planet that we will strike when we continue the pattern of growth so far. The desire to continue to grow materially has proven unrealistic on earth. ${ }^{2}$

This system thinking framework helps us to ask specific questions, then reflect on the patterns of events at our own place. After that we can develop an action plan to intervene at a more strategic level, not just respond to events. But also reflect holistically as well, in this case the problem of garbage.

Next we will discuss what approaches we can build from waste management at UIN North Sumatra.

\section{Islamic Theological Approach on Waste Management}

In the Koran it is clear that natural disasters and environmental crises are the result of human activity. Included in the problem of waste, waste that is not managed and ignored will cause disasters. As we have seen, rubbish that is neglected and carelessly disposed of without being properly managed can lead to, among others; floods, landslides from garbage generation, foul odors and air pollution that can damage health. Though garbage is the result of waste from human consumption, then just dumped by humans. Some people throw it into the river. Throw it away on the side of the road while passing work. For the contents of the North Sumatra UIN campus, there are still students who throw garbage from the classroom window, from the vehicle or throwing it into trenches and parks. Without thinking about the consequences of such garbage disposal can damage the environment and damage human health. Isn't the waste generated should be his responsibility

${ }^{2}$ Johan Rockström sangat dikenal dengan proposalnya yang mengidentifikasi batas-batas khusus pada sistem bumi yang beragam. Dia menyebut temuannya dengan batas-batas planet, bahwa bila kita melampaui batas-batas tersebut, kita tidak dapat lagi menikmati kehidupan yang seimbang antara pertumbuhan alam dan manusia. http://news.mit.edu/2017/johan-rockstrom-framework-for-preserving-earth-resilience0926 
to overcome it. Anything that is the responsibility but not implemented can be called a violation.

The occurrence of damage is a result of sin and violations committed by humans, resulting in disruption of balance on land and at sea, as mentioned in the above paragraph. Instead, the absence of that balance, results in torture to humans. The more damage to the environment, the greater the negative impact on humans, including the impact on innocent people around them. For example, we throw garbage into a ditch or river, every day of the year and last for years. Plus there are other people, other people and other people who also throw trash like us, every day throughout the year and years. Then with that cause floods will occur. The water overflows because the downstream part of the river is blocked by the accumulation of garbage that accumulates, the higher the day, it does not make us sinful. Because we contribute to the occurrence of floods, floods damage the environment and can even cause loss of life, property and property. ${ }^{3}$

Yet if everyone does not litter, then managing waste into something useful, all of that will benefit the human being itself. Especially now that there is a good waste management system, starting from sorting, collecting, processing and recycling, all of which can provide benefits and blessings for humans. We should, especially as Muslims, have to take care of ourselves not to make damage as a form of our charity and piety by doing good by managing waste, (Al-A'raf: 96); (Shura: 30-31)

This approach to Islamic theology is a trigger factor within each individual not to do acts that Allah does not like. This theological approach will instill the divine values in each individual to do good even in the case of garbage which some people consider to be very useless at all, so that managing waste is also considered not useful at all.

The approach of Islamic theology also teaches the people not to behave redundantly. It means that with the development of modern technology now and the development of human knowledge we see that waste is a useful object. Removing useful objects and not using them is redundant. (QS Al Isra: 26 -27)

${ }^{3}$ Direktorat Pembinaan Perguruan Tinggi Agama Islam, Ilmu Fiqih (Jakarta: t.p, 1983), h. 352-362. 
1. Educational Approach: Moral and Character Education in Waste Management

The education approach can be carried out to overcome the problem of waste, especially on the campus of UIN North Sumatra. Education approaches can be done from various aspects, especially moral and character education.

Before forming educated characters and characters about waste management, educated participants must be equipped with knowledge about waste and waste management. After that, they are equipped with moral education and characters that give birth to a positive attitude towards waste and waste management.

Attitude to care about waste and its management is considered from the part of concern for the environment. The attitude can be seen from the behavior shown in daily life. For example, the behavior of not littering like throwing garbage into the river, into the ditch or just throwing away, then the behavior also chooses and sorting garbage. This attitude is very good, to overcome the many problems of garbage that damage the environment.

Behavior towards garbage also originates from knowledge and selfawareness. A person's knowledge is a belief that encourages positive or negative behavior towards an object. Belief in growing love for good will give birth to good deeds that come from conscience. Good behavior toward the environment displayed by campus residents is still though still in the habituation stage.

Introducing moral and character education that gives rise to a positive attitude towards waste and its management must go hand in hand with the provision of knowledge about waste and its management as well. This is so that when a positive attitude has emerged and will be applied there is knowledge that supports the behavior that will be raised by each educated. Now in this case it should be directly supported by facilities and infrastructure through the garbage bank, so that the attitude, knowledge and behavior are immediately applied properly, so that the goal of overcoming the waste problem can be realized.

2. Social Approach to Waste Management: Integrated Cooperation

The social approach is very effective in overcoming the problem of waste on the campus of UIN North Sumatra. The social approach can be done 
since the beginning of the plan to overcome the waste problem by managing it. done with the typology of location, typology of participation, and typology of authority that produces infrastructure development strategies, community participation strategies, and institutional management strategies. These strategies can support social acceptability and participation of campus residents in the implementation of campus-based waste management.

\section{CONCLUSION}

Waste Management at UIN North Sumatera campus has been carried out by outsourcing. The concern of the campus community both among lecturers and students was quite good with the formation of the Garbage Compassion group and the Plastic Diet group; also in the form of training on waste management. Evaluation of Waste Management at UIN North Sumatra Medan was analyzed using approach 3 (three approaches); Islamic Theology of Waste Management; Moral and Character Education Approach in Waste Management and Social Approach to Waste Management. With theological approach, character approach and social approach are expected to generate integrated care.

From the results carried out, it still seems that things need to be developed more seriously through further research and action. First the truly binding policy of the leadership on waste management on campus. Secondly, the need for a thirdoriented economic waste management, needs coordination good relationship between campus and the community in terms of waste management on campus. These three things become part of the empty space and can be developed in further studies. 


\section{DAFTAR PUSTAKA}

Achillas, C., Moussiopoulos, N., Karagiannidis, A., Banias, G., dan Perkoulidis, G. "The Use of Multicriteria Decision Analysis to Tackle Waste Management Problems: A literature review." Waste Management $\mathcal{E}$ Research, Vol. 31, No. 2, 2013.

Bertalanffy, Ludwig von dan Jay Forrester, Perspectives on General System Theory. Laszlo 1974.

De Souza, R.V.B. dan Carpinetti. L.C.R. A FMEA-based approach to prioritize Waste Reduction in Lean Implementation." International Journal of Quality E Reliability Management. Vol.31 No.4, 2014.

Direktorat Pembinaan Perguruan Tinggi Agama Islam, Ilmu Fiqih. Jakarta: t.p, 1983.

Djuli, Murtadho dan Sa'id E. Gumbira, Penanganan dan Pemanfaatan Limbah Pada. Jakarta: Melton Putra, 1988.

Ermis. Meitanti, Partisipasi Masyarakat dalam Pengelolaan Sampah Kota melalui Reduce, Reuse, Recycle. Yogyakarta : Koleksi Karya Ilmiah Perpustakaan Universitas Gadjah Mada,2014.

Hasyimsyah, dkk, Sejarah Universitas Islam Negeri Sumatera Utara. Medan : Lembaga Penelitian dan Pengabdian pada Masyarakat (LP2M) UIN Sumatera Utara, 2016.

http://www.solopos.com/2014/01/22/gagasan-pengelolaan-kampus-ramahlingkungan-483977

Kementrian Negara Lingkungan Hidup Republik Indonesia dan JICA (Japan International Cooperation Agency). Pedoman Mapping 3R. Jakarta : tnp, tt.

Krajhanzl, J. “Environmental and Proenvironmental Behavior." Journal of Health Education, 2010.

Lickona, T. 1996. "Eleven Principles of Effective Character Education", The Journal of Moral Education, 25 (1).

Meadows, Donella, J. Randers and D. Meadows. Limits to Growth. New York: Universe Books, 1972. 
Mulasari, Surahma Asti. dkk, "Kebijakan Pemerintah dalam Pengelolaan Sampah Domestik", Kesmas, Jurnal Kesehatan Masyarakat Nasional, Vol. 8, No. 8, Mei 2014.

Northwest earth Institute, :A Systems Thinking Model: The Iceberg" https://www.nwei.org/iceberg/

Odum, Eugene. Fundamentals of Ecology. Michigan: Saunders, 1953.

Puspitawati, Yuni dan Mardwi Rahdriawan. "Kajian Pengelolaan Sampah Berbasis Masyarakat dengan Konsep 3R (Reduce, Reuse, Recycle) di Kelurahan Larangan Kota Cirebon," dalam Jurnal Pembangunan Wilayah dan Kota UNDIP, Vol. 8 No. 4, Desember 2012.

Rizal, Mohamad. "Analisis Pengelolaan Persampahan Perkotaan (Studi Kasus pada Kelurahan Boya Kecamatan Banawa Kabupaten Donggala)," Jurnal SMARTek, Vol. 9 No. 2. Mei 2010.

Septian, Yoga "Perilaku Ramah Lingkungan Peserta Didik SMA" dalam Sosio Didaktika: Social Science Education Journal, Vol. 3 No. 2 Tahun 2016.

Sugiarto, Anto Tri._Beda Penanganan Sampah Jakarta dengan di Jepang Menurut Peneliti LIPI," 2015, http://lipi.go.id/berita/single/BedaPenanganan-Sampah-Jakarta-dengan-di-Jepang-Menurut-PenelitiLIPI/10510, diakses 25 juni 2017.

The World Bank. World Development Report 2010: Development and Climate Change, terj. Chriswan Sungkono. Jakarta : Salemba Empat, 2010.

Zuhdi, Achmad Cholil. "Krisis Lingkungan Hidup dalam Perspektif Alquran", Mutawâtir, Jurnal Keilmuan Tafsir Hadis, Vol. 2, Nomor 2 Desember 2012. 
FITRAH Jurnal Kajian Ilmu-ilmu Keislaman

Vol. 05 No. 2Desember 2019

REVIEW OF ISLAMIC LAW TO THE USE OF ARTICLE 28 SUBSECTION 2 ABOUT SPEECH HATRED AND DEFAMATION (UU NUMBER 19 AT 2016 AMENDMENTS

TO UU NUMBER 11 AT 2018)

ARBANUR RASYID

IAIN Padangsidimpuan

Email: rasyidarbanur@gmail.com 